\title{
TOTAL PHENOLIC AND FLAVONOID CONTENT, ANTIOXIDANT ACTIVITY AND ANTIMICROBIAL POTENTIAL OF PHLOMIS PUNGENS WILLD
}

\author{
Yehor Bazavluk \\ Student, Lviv Polytechnic National University, \\ e-mail: egor.bazavluk@gmail.com, orcid.org/0000-0003-0408-1605, Ukraine \\ Vira Hamada \\ Postgraduate student, Lviv Polytechnic National University, \\ e-mail: vrhamada@gmail.com, orcid.org/0000-0002-5450-1666, Ukraine \\ Nataliya Polish \\ Postgraduate student, Lviv Polytechnic National University, \\ e-mail: polishn@ukr.net, orcid.org/0000-0002-1676-1053, Ukraine

\section{Roksolana Konechna} \\ Associate Professor, Ph.D., Lviv Polytechnic National University, \\ e-mail: rkonechna@ukr.net, orcid.org/0000-0001-6420-9063, Ukraine

\section{Solomiia Mykytiuk} \\ Student, Danylo Halytsky Lviv National Medical University, \\ e-mail: solomiiamykytiuk@ukr.net, orcid.org/0000-0003-2080-7322, Ukraine

\section{Volodymyr Novikov} \\ Professor, Ph.D., DSc, Lviv Polytechnic National University, \\ e-mail: volodymyr.p.novikov@lpnu.ua, orcid.org/0000-0002-0485-8720, Ukraine
}

\begin{abstract}
The objective of the present study was to determine the total content of phenolics and flavonoids in ethanol extracts of Phlomis pungens Willd. The total phenolic content was estimated spectrophotometrically using Folin Ciocalteu method. The total flavonoid content was measured by aluminium chloride colorimetric assay. The antioxidant and antimicrobial effects of the extracts were investigated. The Phlomis pungens Willd can be regarded as a promising natural plant source of antimicrobial and antioxidant effects with high potential for phytopreparations.
\end{abstract}

Keywords: Lamiaceae, extracts, bioactive compounds, biological activity, phytopreparations

DOI: http://dx.doi.org/10.23856/3713

\section{Introduction}

Despite significant advances in modeling and creation of synthetic drugs, the popularity of herbal therapy is increasing and its competence is expanding. Medicinal plants contain evolutionarily formed complexes of native substances engaged in complex interactions. Thus, despite the pronounced pharmacological effect of the active substances in herbal preparations, their ultimate therapeutic effect on human organs and functional sytems is due to numerous actions and interactions of all components of the complex of bioactive compounds.

Natural drugs are known to have a milder effect than synthetic agents. Undesirable side effects of drugs, including those of synthetic origin, are observed in 10-40\% of patients and are one of the obstacles in the development of new drugs. The percentage of side effects 
significantly increases during self-medication. Thus in more than $60 \%$ cases of selfmedication there was observed irrational and unjustified use of drugs. Side effects are particularly dangerous for vulnerable groups of people, such as elderly patients, pregnant women, patients with impaired renal and hepatic function, and in cases of polytherapy.

Human body reacts and tolerates phytopreparations more easily than synthetic drugs, at this, fewer side effects are observed. So it is promising to expand the range of herbal medical products with new effective plant-based preparations, in particular those based on the herbs widely used in ethnomedicine.

One of the most relevant and promising representatives of the Ukrainian flora to be used in modern medicine and pharmacy is a plant from the family of Lamiaceae - Phlomis pungens Willd. This plant is typical for the ethnopharmacology of Turkey, Syria, and East Slavic peoples. It was used for treating disorders of the gastrointestinal tract, cardiovascular system, infectious diseases and more. The complex of bioactive compounds of the plant has an anti-inflammatory, antimutagenic, antifungal, antiviral and antitumor activity (Öztürk et al., 2016; Dalar et al., 2013; Ciocarlan, 2016).

The Phlomis pungens growth range extends from the south of Europe and northwest of Africa to Central Asia (Mathiesen, 2011). Plant populations were found in Crimea, Bulgaria, Turkey, Caucasus, southern Russia (Protopopova et al., 2006). In Ukraine, it occurs in steppes, steppe slopes and stony outcroppings, mostly in the steppe part, rarely in the southern forest-steppe (Kyiv, Poltava, Zaporizhia, Donetsk regions etc.).

Phlomis pungens in a raw form is rich in essential oils, the main components of which are monoterpenes ( $\alpha$-pinene, linalool, D-limonene), sesquiterpenes ( $\beta$-caryophyllene, $\alpha$ cadinol, germacrene D, caryophyllene oxide, n-farnesene) hexadecanoic acid, hexahydrofarnesyl acetone, trans-phytol, 9,12,15-octadecatrien-1-ol, etc. (Sarikurkcu et al., 2016; Kirimer et al., 2017). Masoudi et al. (2006) conducted studies showing that germacrene $\mathrm{D}(24.5 \%)$, bicyclogermacrene (14.1\%), $\alpha$-pinene $(13.5 \%)$, and $(\mathrm{E})-\beta$ - farnesene $(13.4 \%)$ are the main constituents of the essential oils. Sarikurkcu et al. (2016) report about the highest content of germacrene D (7.2\%) and n-hexadecanoic acid in the essential oils.

In addition to essential oils, the complex of biologically active compounds is represented by iridoids, flavonoids, phenylpropanoids, phenylethanides, lignans, neolignans, terpenoids, alkaloids (Taskin et al., 2018), micro- and macroelements (including calcium, magnesium, cuprum, manganese, zinc, cobalt) (Kruglaya, 2006).

The purpose of our study is to investigate the chemical composition of the ethanol extracts of Phlomis pungens Willd., in particular phenolic compounds and flavonoids and to study their antimicrobial and antioxidant effects.

\section{Material and methods}

\subsection{Plant material}

Harvesting of medicinal plant material (Phlomis pungens Willd. herb) was carried out in ecologically clean regions of central Ukraine in summer 2019. Drying and standardization were carried out according to the requirements of the State Pharmacopoeia of Ukraine.

\subsection{Preparation of extracts}

The extracts were obtained by maceration. Aqueous ethanol solutions in concentrations of 20\% (PP1 extract), 40\% (PP2 extract), 70\% (PP3 extract) and 90\% (PP4 extract) were used as extractants. The ratio of raw material and extractant was 1:20. 


\subsection{Determination of total phenolic content}

The determination was performed using a spectrophotometric analysis using a modified Folin-Ciocalteu method. $1 \mathrm{ml}$ of Folin reagent, $20 \mathrm{ml}$ of distilled water and $3 \mathrm{ml}$ of $20 \% \mathrm{Na} 2 \mathrm{CO} 3$ solution were added to $1 \mathrm{ml}$ of the analyzed solution, diluted in a ratio of 1:20. The prepared mixture was shaken for $10 \mathrm{~min}$, then kept in a water bath at $40{ }^{\circ} \mathrm{C}$ for $20 \mathrm{~min}$. The solution was cooled and the optical density of the resulting solution was measured at 760 $\mathrm{nm}$. The conversion was performed per gallic acid according to a calibration curve that was constructed under similar conditions, replacing the analyte with the gallic acid solution used as standard. A 3-fold measurement was performed for data validity (Skotti et al., 2014; Krvavich et al., 2019).

\subsection{Determination of total flavonoid content}

The amount of flavonoids was determined by a modified spectrophotometric method by the complexation reaction of flavonoids with $\mathrm{AlCl} 3$. For this purpose, a $5 \%$ solution of $\mathrm{NaNO} 2$, a $0.1 \mathrm{M}$ solution of sodium hydroxide $\mathrm{NaOH}$ and a $10 \%$ solution of $\mathrm{AlCl} 3$ were prepared. $0.2 \mathrm{ml}$ of the obtained Phlomis pungens herb extract was taken into a test tube and dissolved in $0.8 \mathrm{ml}$ of ethyl alcohol. $0.06 \mathrm{ml}$ of $5 \%$ sodium nitrite solution was added and mixed together. After that, the tube was kept for $5 \mathrm{~min}$ in a dark place. $0.06 \mathrm{ml}$ of a $10 \%$ solution of aluminum chloride was added and kept for $5 \mathrm{~min}$ in the dark place until the reaction was complete. Then $0.4 \mathrm{ml}$ of $0.1 \mathrm{M}$ sodium hydroxide solution and $0.275 \mathrm{ml}$ of ethyl alcohol of appropriate concentration were added. The measurements were performed at a wavelength of $510 \mathrm{~nm}$. For calibration, a standard curve was constructed using the solution of quercetin as standard, and the content of flavonoids was determined in terms of quercetin. A 3-fold measurement was performed for the accuracy of the data (Do et al., 2014).

\subsection{Determination of antimicrobial potential}

The study of antifungal activity was carried out on standard microorganism cultures Candida albicans (ATCC 885-653) and C. albicans (ATCC 668-853); clinical strains of microorganisms C. albicans №12 (polyantibiotic-resistant), C. albicans №3, nystatin-resistant (nis), sensitive to itraconazole and fluconazole; and C. albicans №6, resistant to azoles (ketoconazole - ket), sensitive to nystatin. Investigations of promicrobial activity were performed on standard cultures of Escherichia coli (ATCC 25922), Staphylococcus aureus (ATCC 25923 (F-49)), Staphylococcus epidermidis 191, Bacillus subtilis (ATCC 6633), Pseudomonas aeruginosa (ATCC 27853 (F-51)). The method of diffusion into agar was used and the serial dilution method, taking into account the bactericidal action of ethyl alcohol (State Pharmacopoeia of Ukraine, Paragraph 2.7, p. 139).

\subsection{Determination of the antioxidant effect \\ 2.6.1 DPPH radical scavenging effect}

The DPPH method of measuring the antioxidant effect of the extract was used with some modifications. Freshly prepared solution of DPPH was about $0.1 \mathrm{mM}(0.2 \mathrm{~g} \mathrm{DPPH}$ in $500 \mathrm{~mL}$ of ethanol). $4.5 \mathrm{~mL}$ of solution of DPPH and $500 \mu \mathrm{L}$ of the extract were mixed in a test tube, which was incubated for 30 minutes in the dark at room temperature. A UV-VIS spectrophotometer was used for measuring the decrease in absorbance (at $517 \mathrm{~nm}$ ). The following formula was used for calculating percentage of inhibition of the radicals: 


$$
\%_{\text {inhibition }}=\frac{\left(\mathrm{A}_{\text {control }}-\mathrm{A}_{\text {sample }}\right)}{\mathrm{A}_{\text {control }}} \times 100 \%
$$

where $A_{\text {control }}$ is the absorbance of DPPH solution without extract and $A_{\text {sample }}$ is the absorbance of the sample with the added DPPH solution. A 3-fold measurement was performed for the accuracy of the data (Do et al., 2014).

\subsubsection{ABTS radical scavenging effect}

The extract's free radical scavenging effect was also determined by ABTS radical cation decolorization assay. Concentration of ABTS was dissolved to a $0.014 \mathrm{mM}$ in water. Reacting the original ABTS solution with a solution of potassium persulfate (prepared by dissolving $0.0135 \mathrm{~g} \mathrm{~K} 2 \mathrm{~S} 2 \mathrm{O} 8 \mathrm{in} 10 \mathrm{ml}$ of water) gave a possibility to obtain a radical cation $\operatorname{ABTS}(\mathrm{ABTS} *)$ and then the mixture was stirred in the dark at room temperature for $20 \mathrm{~h}$. After that $1 \mathrm{ml}$ of the resulting solution was diluted to $100 \mathrm{ml}$. There was taken reagent blank reading $\left(\mathrm{A}_{\text {control }}\right)$. The absorbance reading was taken after addition of $1.0 \mathrm{~mL}$ of diluted ABTS $^{*}+$ solution to $100 \mu \mathrm{L}$ of the extract exactly 6 min after initial mixing at $30{ }^{\circ} \mathrm{C}$ ( $\mathrm{A}_{\text {sample }}$ ). Blanks of appropriate solvent were run in each assay. A 3-fold measurement was performed for the accuracy of the data (Katalinic et al., 2006).

\section{Results \\ 3.1 Total phenolic and flavonoid contents}

The total content of phenolic compounds in the investigated extracts was determined, the result is expressed in $\mathrm{mg}$ of gallic acid per $\mathrm{g}$ of plant material. The total content of flavonoids was determined, the result is expressed in $\mathrm{mg}$ of quercetin per $\mathrm{g}$ of plant material. The results are presented in Table 1.

Table 1

Total phenolic and flavonoid content of $P$. pungens extracts

\begin{tabular}{|c|c|c|}
\hline Sample & $\begin{array}{c}\text { Total phenolic content } \\
(\text { mg gallic acid/g) } \\
\bar{x} \pm \Delta \bar{x}, n=4\end{array}$ & $\begin{array}{c}\text { Total flavonoid content } \\
\left(\mathbf{m g}_{\bar{x}} \text { quercetin/g) }\right.\end{array}$ \\
\hline PP1 & 2.6055 & 2.1187 \\
\hline PP2 & 3.2010 & 2.6604 \\
\hline PP3 & 4.1356 & 3.3314 \\
\hline PP4 & 4.9711 & 3.2503 \\
\hline
\end{tabular}

The content of phenolic compounds in the tested extracts ranged from 2.6055 to 4.9711 $\mathrm{mg} / \mathrm{g}$. The highest value was observed for the PP4 extract, the extractant being $90 \%$ aqueous ethanol solution. The content of flavonoids in the tested extracts ranged from 2.1187 to 3.3314 $\mathrm{mg} / \mathrm{g}$. The highest value was observed for the PP3 extract, the extractant being $70 \%$ aqueous-ethanol solution. 


\subsection{Antioxidant activity}

There were used two assays: DPPH radical and ABTS radical cation assays for the sake of appreciation of free radical scavenging properties of Phlomis pungens extracts. Table 2 shows the results of the analysis.

For the evaluation of antioxidant activity of single compounds has been widely used relatively stable organic radical DPPH as well as the different plant extracts. A rapid decrease in the optical density at $517 \mathrm{~nm}$ was induced by the addition of extracts to the DPPH solution. The effect of Phlomis pungens extracts of different concentrations in comparison with quercetin and vitamin $\mathrm{C}$ on the inhibition of DPPH radical is shown in Table2.

Table 2

DPPH and ABTS radical scavenging activity of $P$. pungens extracts

\begin{tabular}{|c|c|c|}
\hline Sample & \% inhibition of DPPH* & $\begin{array}{c}\text { \% inhibition of ABTS radical } \\
\text { cation }\end{array}$ \\
\hline PP1 & 86.3075 & 87.0146 \\
\hline PP2 & 88.2589 & 89.1734 \\
\hline PP3 & 90.6109 & 91.8641 \\
\hline PP4 & 91.6431 & 91.9972 \\
\hline Vitamin C & 79.5060 & 89.6938 \\
\hline Quercetin & 89.2298 & 88.0837 \\
\hline
\end{tabular}

Our investigation shows that free radical scavenging ability of PP3, PP4 extracts was better than quercetin. Under the test conditions, Phlomis pungens extracts with vitamin $\mathrm{C}$ were better DPPH radical scavengers.

The ability to release free radicals of Phlomis pungens extracts was also determined through the ABTS radical cation. It is often used to evaluate the antioxidant activity of individual bioactive compounds as well as mixtures of various origins. In this investigation, a stable form of the ABTS radical cation was formed directly by using potassium persulfate. The interference of compounds that affect the formation of radicals before the addition of antioxidants is prevented by generation of the radical. This option makes the investigation less susceptible to artifacts and averts reassesment of antioxidant ability. A sample of antioxidant is added after stable absorption is received to the reaction medium and the antioxidant activity is measured by discoloration. The results prove that PP2, PP3, PP4 extracts improve the scavengers of radical ABTS cations more than vitamin $\mathrm{C}$ or quercetin.

\subsection{Antimicrobial potential}

Antifungal effect of Phlomis pungens extracts (20\%, 70\%, 90\% of ethanol) was manifested against Candidaalbicans 653, Candida albicans 853 and clinical strains Candida albicans (nis), Candidaalbicans (ket and nis) including the polyresistant Candida albicans № 12. The greatest antifungal action against the polyresistant strain of Candida albicans № 12 was shown by the extract with $70 \%$ concentration of ethanol.

There were revealed the following antimicrobial effects of the Phlomis pungens extract with different concentrations of ethanol: 
Phlomis pungens extract (20\% of ethanol) affects Bacillus subtilis museum strain and Pseudomonas aeruginosa clinical strain;

Phlomis pungens extract (40\% of ethanol) affects Bacillus subtilis museum strain;

Phlomis pungens extract $(70 \%$ of ethanol) affects Staphylococcus aureus, Bacillus subtilis museum strains and Staphylococcus aureus clinical strain.

According to the results obtained, all extracts, irrespective of ethanol concentration, demonstrated the best antibacterial effects on the Bacillus subtilis museum strain.

\section{Conclusions}

The research done into the chemical composition of Phlomis pungens Willd ethanol extracts discovered the quantitative content (strength) of phenol compounds and flavonoids as well as examined their antimicrobial, antifungal and antioxidant effects. Sufficient content of phenol compounds and flavonoids as well as revealed antimicrobial and antifungal effects of the extracts under study allow to consider Phlomis pungens Willd a promising medical herb for developing herbal preparations and to conduct further studies of the plant.

\section{References}

Ciocarlan, N. (2016). Family Lamiaceae: main important spontaneous medicinal and aromatic species in the Republic of Moldova. Journal of Botany, VIII, 1(12), 86-91. [in English].

Dalar, A. (2013). Phenolic contents, antioxidant capacities and inhibitory activities against key metabolic syndrome relevant enzymes of herbal teas from Eastern Anatolia. Industrial Crops and Products, 44, 383-390. DOI: 10.1016/j.indcrop.2012.11.037. [in English].

Do, Q. D. (2014). Effect of extraction solvent on total phenol content, total flavonoid content, and antioxidant activity of Limnophila aromatica. Journal of Food and Drug Analysis, 22, 296-302. DOI:10.1016/j.jfda.2013.11.001. [in English].

Katalinic, V. (2006). Screening of 70 medicinal plant extracts for antioxidation capacity and total phenols. Food Chemistry, 94, 550-557. DOI:10.1016/j.foodchem.2004.12.004. [in English].

Kirimer, N. (2017). Essential oil constituents of Phlomis pungens Willd. from Azerbaijan. Journal of Essential Oil Bearing Plants, 20(6), 1492-1501. DOI:10.1080/0972060X.2017.1407261. [in English].

Kruhlaia, A. A. (2006). Macro- and micro-elemental composition of herbs of knitted barbar and pornlous-bed bird, growing in the North Caucasus. Vestnyk VHU, Seriia: khimiia, biolohiia, farmatsyia, 2, 294-296. [in Russian].

Krvavych, A. S., Hamada, V. R., Konechna, R. T., Mylyanych, A. O., Zhurakhivska, L. R., Buchkevych, I. R., Novikov, V.P. (2019). Extraction of phenolic compounds from the Plant Adonis Vernalis. Voprosy khimii i khsmscheskoi tekhnolohii, 5, 54-57. DOI:10.32434/03214095-2019-126-5-54-57. [in Ukrainian].

Masoudi, S. (2006). Composition of the essential oils of Cyclotrichium straussii (Bornm.) Rech.f. and Phlomis pungens Willd. from Iran. Journal of Essential Oil Research, 18(1), 1618. DOI:10.1080/10412905.2006.9699373. [in English].

Mathiesen, C. (2011). Phylogeny and biogeography of the lamioid genus Phlomis (Lamiaceae). Kew Bulletin, 66, 83-99. [in English]. 
Öztürk, M. (2016). Herbals from the High Mountains in the East Mediterranean. Drug Discovery from Herbs: Approaches and Applications, 24, 327-367. [in English].

Protopopova, V. V. (2006). The history of introduction and present distribution of Elaeagnus angustifolia L. in the Black Sea Region of Ukraine. Chornomorskyi botanichnyi zhurnal, 2(2), 5-13. [in English].

Sarikurkcu, C. (2016). Chemical composition, antioxidant, and enzyme inhibitory activities of the essential oils of three Phlomis species as well as their fatty acid compositions. Food Science and Biotechnology, 25(3), 687-693. DOI:10.1007/s10068-016-0120-9. [in English].

Skotti, E. (2014). Total phenolic content, antioxidant activity and toxicity of aqueous extracts from selected Greek medicinal and aromatic plants. Industrial Crops and Products, 53, 4654. DOI:10.1016/j.indcrop.2013.12.013. [in English].

Taşkın, T. (2018). Antioxidant and anti-inflammatory activities of Phlomis pungens and Coridothymus capitatus. Marmara Pharmaceutical Journal, 22(1), 80-85. DOI:10.12991/mpj.2018.44. [in English]. 